\title{
Optimization of Thermal Preprocessing for Efficient Combustion of Woody Biomass*
}

\author{
Seiji KUMAGAI**, Masahiko ARANAI**, \\ Koichi TAKEDA $^{* *}$ and Yukio ENDA ${ }^{* * *}$
}

\begin{abstract}
We attempted to optimize both drying time and temperature for stem chips and bark of Japanese cedar in order to obtain the largest release of combustion heat. Moisture release rates of the stem and bark during air-drying in an oven were evaluated. Higher and lower heating values of stem and bark, dried at different temperatures for different lengths of time, were also evaluated. The drying conditions of $180^{\circ} \mathrm{C}$ and $30 \mathrm{~min}$ resulted in the largest heat release of the stem ( $\sim 4 \%$ increase compared to conditions of $105^{\circ} \mathrm{C}$ and $\left.30 \mathrm{~min}\right)$. The optimal drying conditions were not obvious for bark. However, for the drying process in actual plants, the conditions of $180^{\circ} \mathrm{C}$ and $30 \mathrm{~min}$ were suggested to be acceptable for both stem and bark.
\end{abstract}

Key Words: Biomass, Japanese Cedar, Stem, Bark, Combustion, Heating Value, Drying, Moisture

\section{Introduction}

The eco-friendliness and on-site advantages of thermal power plants that use scrap woods as fuel can contribute to a suppression of greenhouse effects. The nature of decentralized biomass combustion has been studied previously ${ }^{(1)}$. In terms of the merits of both cost and scale, these plants are not competitive with existing largescale power plants. The present share of these power plants in terms of total generated power is extremely low $(\sim 0.01 \% \text { in Japan, } 1999)^{(2)}$. However, the energy policies of many forest-rich countries, such as Sweden, encourage their construction and operation ${ }^{(3)}$. It is important that the disadvantages of biomass thermal power plants be overcome to further their greater acceptance.

Biomass materials, such as scrap wood, are recognized as carbon-neutral fuels. Their hygroscopic nature, which permits the existence of latent moisture and moisture uptake from ambient environments, is an intrinsic shortcoming of such fuels. Nevertheless, the heating value provided by biomass combustion can be converted into

* Received 23rd May, 2005 (No. 05-4100)

** Department of Machine Intelligence and Systems Engineering, Akita Prefectural University, 84-4 Tsuchiya-azaebinokuchi, Yurihonjo, Akita 015-0055, Japan.

E-mail: kumagai@akita-pu.ac.jp

*** Environmental System Department, Industrial Technology Center of Akita Prefecture, 4-11 Arayamachi-azasanukiyori, Akita 010-1623, Japan electric power. Moisture vaporization is an endothermic reaction. Thus, nondried biomass simply reduces the amount of generated power, as well as causing a sudden sag of generated power, which can lead to a failure of the plant and a resultant destabilization of the connected public power system.

A drying process, using the waste heat of the plant, is incorporated for wet wood prior to its use ${ }^{(4)}$. The drying characteristics of wood have been studied in terms of initial moisture content and theory of heat transfer ${ }^{(5),(6)}$. Cellulose, hemicellulose, and lignin are the three primary constituents of wood. Hemicellulose allows chain scission, ring-opening, and dehydration at greater than $200^{\circ} \mathrm{C}$. Higher drying temperatures can remove moisture in wood in a shorter period of time. However, they may also cause environmental pollution and remove volatile components that provide part of the heating value of combustion ${ }^{(7)-(9)}$. It is of significant social benefit to optimize drying conditions of this process in order to achieve selective removal of moisture without additional component loss. There have been few reports to date on the drying performance of biomass, based on the heating value of dried materials.

The purpose of the present study was to determine the optimal drying conditions to attain the largest combustion heat release of stem chips and bark of Japanese cedar. The stem and bark of Japanese cedar are typical scrap wood in Japan. The optimal drying conditions were determined based on moisture release rate, loss of wood constituents, and higher and lower heating values under different drying 
times and temperatures.

\section{Experimental Details}

\subsection{Samples}

Japanese cedar (Sugi, Cryptomeria japonica D. Don), grown in Akita Prefecture, was used as the sample source. Raw stems were chopped in a chipping machine, but were not separated into sap and heart wood. The chips whose dimensions were 40-60 mm (L) $\times 8-12 \mathrm{~mm}(\mathrm{~W}) \times 6-$ $10 \mathrm{~mm}(\mathrm{~T})$ were selected. Raw bark was collected with a debarking machine. The bark was cut into pieces of dimensions 40-60 $\mathrm{mm}(\mathrm{L}) \times 8-12 \mathrm{~mm}(\mathrm{~W}) \times 3-6 \mathrm{~mm}$ (T). These pre-selected stem chips and pieces of bark were air-dried at $105^{\circ} \mathrm{C}$ in an electric oven (DRM420DA, Advantec, Japan). The weights of the stem chips and pieces of bark during drying stabilized at $30 \mathrm{~min}$ and $180 \mathrm{~min}$, respectively. Both sample types weighed between 0.5 and $1.0 \mathrm{~g}$, and were employed as starting samples. Figure 1 shows their typical appearance.

\subsection{Water absorption and drying}

The starting samples were immersed in distilled water between 22 and $24^{\circ} \mathrm{C}$ for water absorption until the sample weight reached a constant value (stem chips: $10 \mathrm{~min}$; bark: $120 \mathrm{~min}$ ). In order to observe drying behavior, wet samples were air-dried in an electric oven, whose internal temperature had been set to the appropriate drying temperature. Moisture content was defined as

\section{Moisture content $=$}

(Wet weight - Dry weight $) /($ Dry weight $) \times 100(\%)$,

where dry weight is the weight of the starting sample. The drying times (i.e., moisture content $<20 \%$ and $<5 \%$ ) were measured at different drying temperatures, ranging from 105 to $240^{\circ} \mathrm{C}$.

\subsection{Thermal gravimetry}

A thermal gravimetry (TG) system (6300, Seiko Instruments, Japan) was employed to observe weight changes of the dried and wet stem chips and pieces of bark with a constant rise in temperature. Small sections cut from the starting samples $(\sim 5 \mathrm{mg})$, as well as samples immersed in distilled water at $22-24^{\circ} \mathrm{C}$ for $5 \mathrm{~min}$ immediately prior to TG, were tested. The small sections were

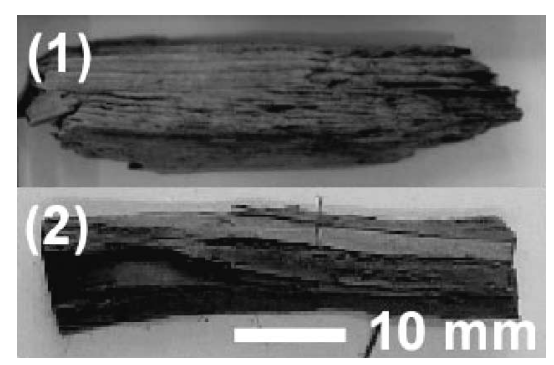

Fig. 1 Typical appearance of samples. (1) stem chip (2) bark heated from 40 to $300^{\circ} \mathrm{C}$ under both air and nitrogen at $200 \mathrm{~mL} / \mathrm{min}$, with a heating rate of $10^{\circ} \mathrm{C} / \mathrm{min}$.

\section{4 Gas chromatograpy-mass spectroscopy}

A gas chromatography-mass spectroscopy (GC-MS) system, consisting of GC (6890A, Agilent Technology, USA) and MS elements (5973N, Agilent), was used to identify volatile components released from the samples heated under inert gas. Using such a system together with TG, it was possible to verify whether moisture or flammable components were released. Small sections cut from the starting samples $(1.0 \mathrm{mg})$ were heated in a pyrolyzer (PY-2020D, Frontier Lab., Japan) at $140-260^{\circ} \mathrm{C}$ for $5 \mathrm{~min}$ under helium $(73 \mathrm{~mL} / \mathrm{min})$. The gases produced from the samples were cooled a $77 \mathrm{~K}$ and condensed prior to injection on the GC column, a DB-1 (J \& W Scientific, USA) capillary in which helium serves as the carrier. The column was subjected to a temperature program of $50^{\circ} \mathrm{C}$ for $1 \mathrm{~min}$, followed by an increase of $15^{\circ} \mathrm{C} / \mathrm{min}$ to $300^{\circ} \mathrm{C}$. Substances detected as peaks on total ion chromatography were analyzed based on their mass spectra and were identified with the NIST 98 database installed on the GC-MS system. Moisture could not be detected by this GC-MS system $(m / z>30)$.

\subsection{Compositional analysis, yield measurement,} and heating value evaluation of dried samples

Stem chips and bark were subjected to compositional analysis. Ash content was determined from the ratio of the weight after incineration at $815^{\circ} \mathrm{C}$ for $1 \mathrm{~h}$ in air to that of the starting samples. A CHNO/S analyzer (2400 II, Perkin-Elmer, USA) was used to determine the hydrogen, carbon, and nitrogen content, as well as the remaining oxygen content. The weight yield of all dried samples was evaluated. The weight of the starting sample was defined as $100 \%$. The higher heating value (HHV) is a heating value produced by the combustion of fuel in which generated water exists as a liquid, while the lower heating value (LHV) is that existing as vapor. The LHV is a well-employed index for actual heat exchangers such as boilers. A calorimeter (CA-4PJ, Shimadzu, Japan) was used to evaluate the HHV of the samples dried at different temperatures $\left(180-260^{\circ} \mathrm{C}\right)$ and for different lengths of time $(0-120 \mathrm{~min})$. The LHV was calculated using the following formula ${ }^{(10)}$ :

$$
\mathrm{LHV}=\mathrm{HHV}-2.52 \times 9 \times(\text { weight content } \text { of } \mathrm{H})[\mathrm{kJ} / \mathrm{g}]
$$

Additionally, the net LHV was calculated for all dried samples using Eq. (3) below. The effectiveness of each drying condition was evaluated based on this net LHV.

$$
\text { Net } \mathrm{LHV}=\mathrm{LHV} \times \text { weight yield }[\mathrm{kJ} / \mathrm{g}]
$$




\section{Results and Discussion}

\subsection{Water absorption and drying characteristics of stem chips and bark}

The starting samples were immersed in distilled water and then dried at $105-240^{\circ} \mathrm{C}$. Figure 2 shows the moisture content after water absorption (before drying) and the time required for the moisture content to return to $20 \%$ or $5 \%$ at different drying temperatures. The moisture content of the stem chips and bark after water absorption are $60 \%$ and $90 \%$, respectively. Bark was able to hold more moisture than stems. It was observed that higher drying temperatures promote moisture release, which can be seen clearly in the time required for the moisture content to return to $20 \%$. Moisture release was less evident in the results for the return to $5 \%$ moisture content, even though the drying temperature was elevated to $180-240^{\circ} \mathrm{C}$.

\subsection{TG characteristics of stem and bark}

TG was performed on both dried and wet stem and bark under air and inert (nitrogen) gas. The weight changed as a function of temperature, as shown in Fig. 3. The sample weight stabilized initially at approximately $140^{\circ} \mathrm{C}$; thus, the sample weight at this temperature was defined as $100 \%$. A large decrease in weight was a result of the vaporization of absorbed moisture at temperatures
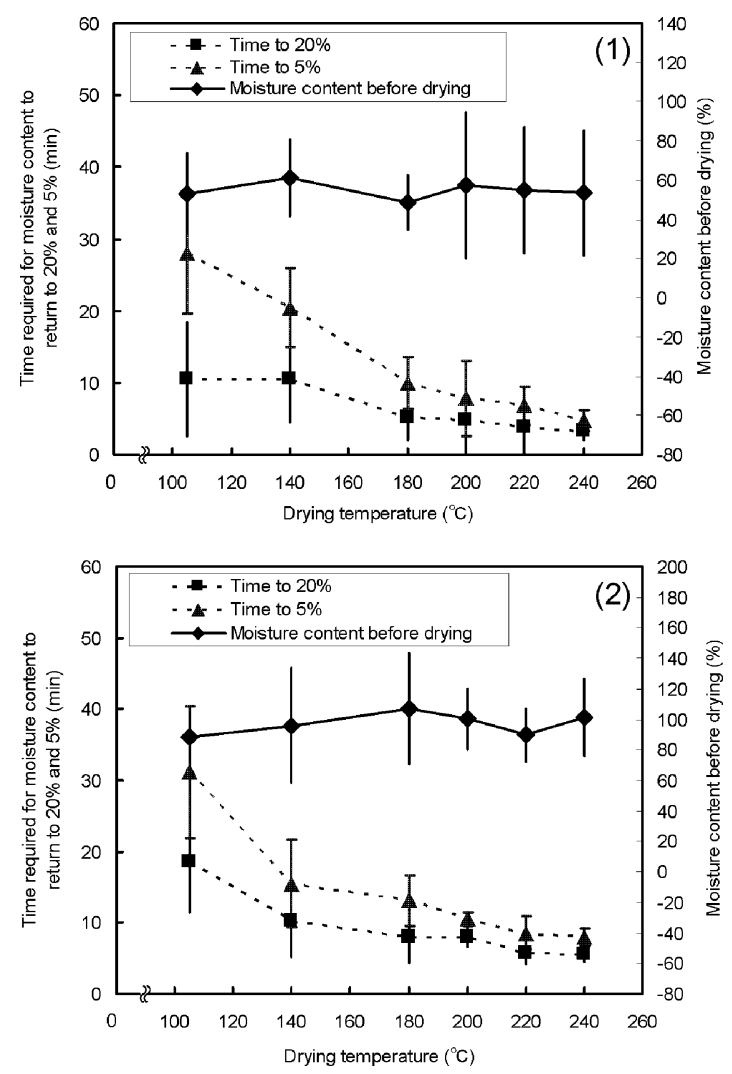

Fig. 2 Moisture content after water absorption and time required for the moisture content to return to $20 \%$ or $5 \%$ after air drying at different temperatures.

(1) stem chips (2) bark less than $120^{\circ} \mathrm{C}$. It should be noted that, unlike in the drying test described in the previous section, small sections $(\sim 5 \mathrm{mg})$ were used here. Under air, weight losses occurred at temperatures greater than $140^{\circ} \mathrm{C}$ for both stem and bark and were independent of water absorption prior to TG. The stem suffered a small weight loss between 140 and $240^{\circ} \mathrm{C}$ and a larger loss at temperatures greater than $240^{\circ} \mathrm{C}$, while the bark suffered a gradual weight loss between 140 and $260^{\circ} \mathrm{C}$. The weight losses of the stem and the bark at $260^{\circ} \mathrm{C}$ were approximately 4 and $6 \%$, respectively, indicating that bark releases more volatile components than stem when air-dried at temperatures less than $260^{\circ} \mathrm{C}$. No differences in weight loss between the two sample types under air or nitrogen were observed between 140 and $240^{\circ} \mathrm{C}$. The weight losses under nitrogen were alleviated at temperatures greater than $240^{\circ} \mathrm{C}$ compared with those under air. However, the degree of alleviation at $260^{\circ} \mathrm{C}$ for both stem and bark was still only $1 \%$.

\subsection{GC-MS for observation of the release of volatile components}

Volatile components released from the small sections of stem and bark $(1.0 \mathrm{mg})$ and heated in inert helium gas were observed by GC-MS. Figure 4 shows the total ion chromatographs of volatile material released from stem and bark heated under helium at $140-260^{\circ} \mathrm{C}$ and volatile
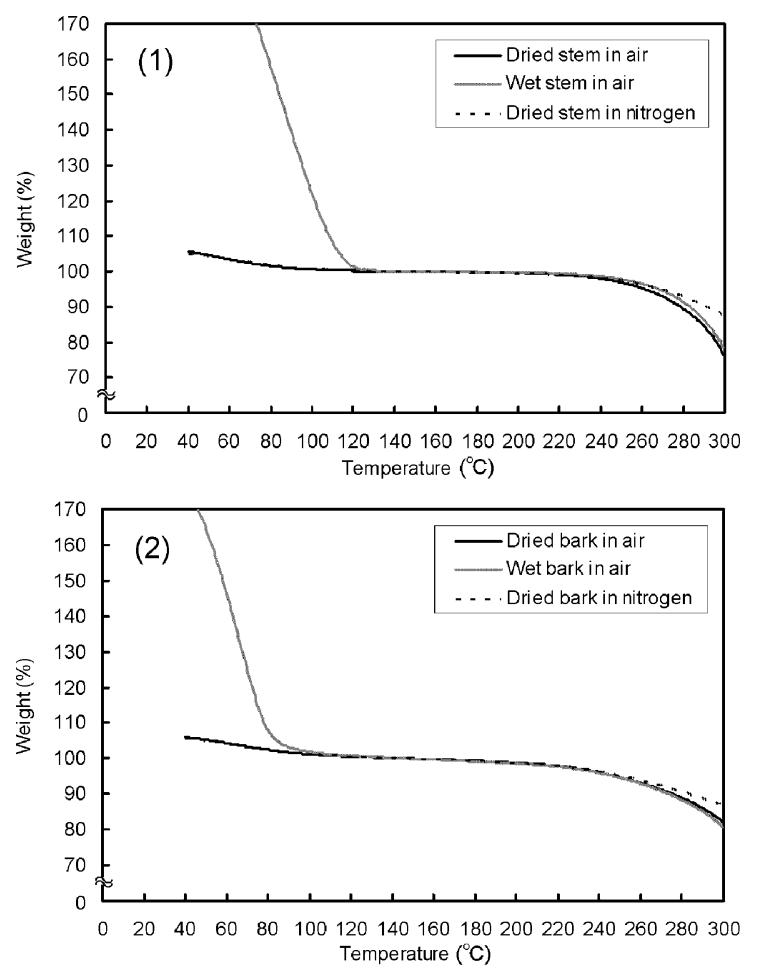

Fig. 3 TG of dried and wet stem and bark under air. The dried samples were the starting samples and the wet samples were the starting samples immersed in water for $5 \mathrm{~min}$ prior to TG. Heating rate: $10^{\circ} \mathrm{C} / \mathrm{min}$; weight at $140^{\circ} \mathrm{C}$ : $100 \%$.

(1) stem (2) bark 

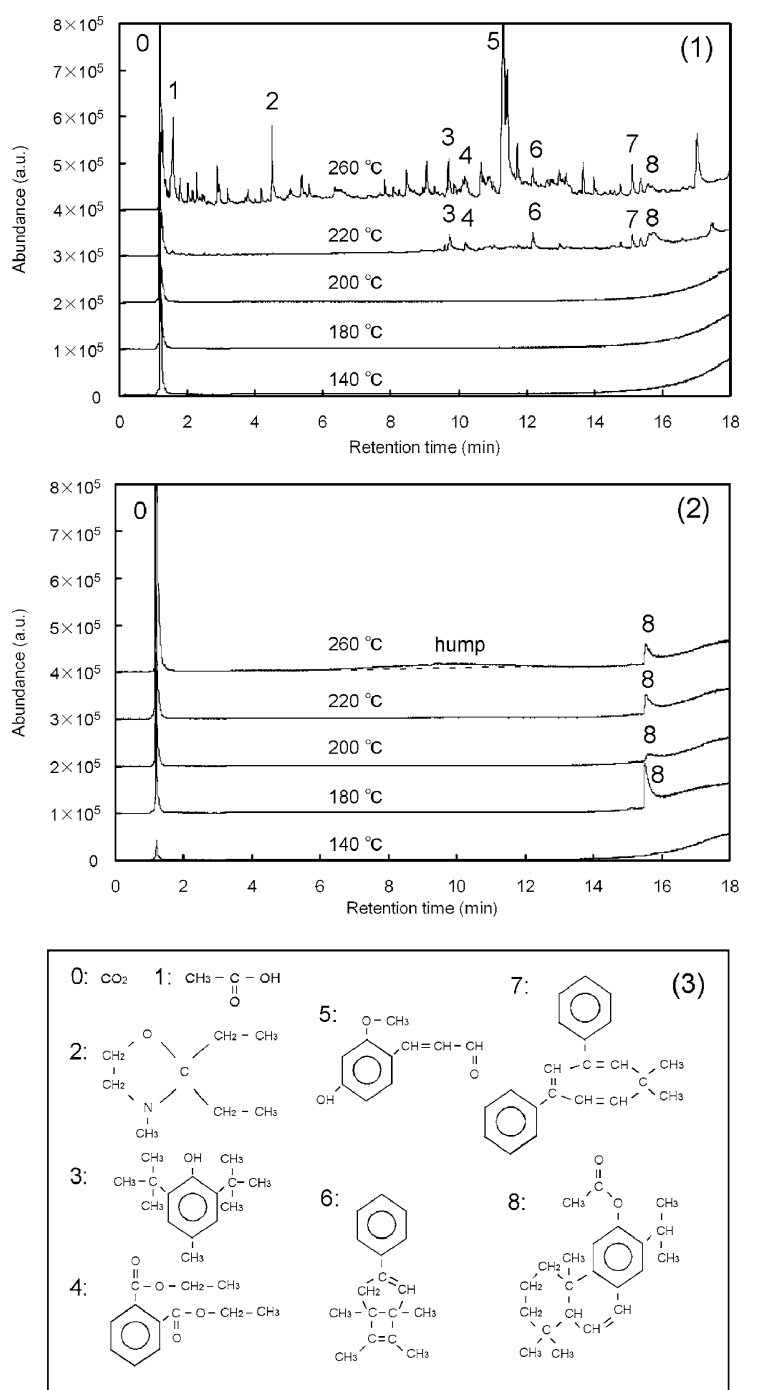

Fig. 4 Total ion chromatographs of volatile material released from stem and bark samples heated at $140-260^{\circ} \mathrm{C}$, and volatile material was identified. The starting samples were heated for $5 \mathrm{~min}$ under helium.

(1) stem (2) bark (3) identification of principally detected substances based on the NIST 98 database

components were identified. Specific peaks due to volatile material appeared on the chromatographs of stem at temperatures greater than $220^{\circ} \mathrm{C}$ and on those of bark at temperatures greater than $180^{\circ} \mathrm{C}$. Stems allow active production of volatile material at $260^{\circ} \mathrm{C}$, and a broad peak was observed on the total ion chromatograph of bark heated at $260^{\circ} \mathrm{C}$ (retention time: $7-12 \mathrm{~min}$ ), which indicates that many types of volatile material were generated. All of the volatile components identified, except for $\mathrm{CO}_{2}$, contribute to the heating value of combustion. The $\mathrm{CO}_{2}$ identified on the chromatographs is not due to thermo-oxidation because the samples were heated under helium gas. We do not provide further chemical interpretation of the identified volatile material because the present study focuses solely on whether or not the detected volatile components contribute to heating value.
Table 1 Composition in weight and weight yield of stem chips dried at different temperatures. Drying time: $30 \mathrm{~min}$

\begin{tabular}{|c|c|c|c|c|c|c|}
\hline $\begin{array}{c}\text { Temp. } \\
\left({ }^{\circ} \mathrm{C}\right)\end{array}$ & $\begin{array}{c}\mathrm{C} \\
(\%)\end{array}$ & $\begin{array}{c}\mathrm{H} \\
(\%)\end{array}$ & $\begin{array}{c}\mathrm{N} \\
(\%)\end{array}$ & $\begin{array}{c}\mathrm{O} \\
(\%)\end{array}$ & $\begin{array}{c}\text { Ash } \\
(\%)\end{array}$ & $\begin{array}{c}\text { Weight } \\
\text { yield }(\%)\end{array}$ \\
\hline 100 & 48.0 & 6.0 & 0.2 & 45.0 & 0.8 & 100.0 \\
\hline 180 & 49.2 & 6.2 & 0.1 & 43.7 & 0.8 & 98.3 \\
\hline 200 & 48.9 & 6.0 & 0.1 & 44.2 & 0.8 & 98.0 \\
\hline 220 & 49.4 & 6.0 & 0.1 & 43.7 & 0.8 & 96.7 \\
\hline 240 & 50.2 & 5.9 & 0.1 & 42.9 & 0.9 & 91.6 \\
\hline 260 & 51.8 & 5.5 & 0.1 & 41.7 & 0.9 & 84.6 \\
\hline
\end{tabular}

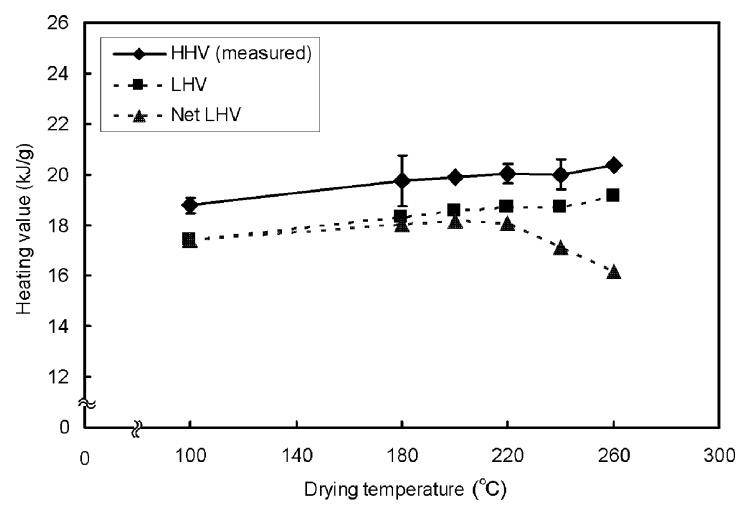

Fig. 5 HHV, LHV, and net LHV of stem chips dried at different temperatures. Drying time: $30 \mathrm{~min}$. The HHVs shown are the average of measured data with standard deviation; the LHV was obtained using Eq. (3) above and the corresponding average HHV. The net LHV is LHV $\times$ weight yield presented in Table 1 .

Results from GC-MS suggest that volatile material is released from the stem at temperatures greater than $220^{\circ} \mathrm{C}$ and from the bark at temperatures greater than $180^{\circ} \mathrm{C}$ under inert conditions. More volatile components were produced under air than under inert conditions due to thermooxidation. TG suggests that the weight variation of both stems and bark at $140-220^{\circ} \mathrm{C}$ under inert nitrogen is similar to that under air. Thus, for air drying, volatile material other than moisture were negligibly released from stem samples at temperatures less than $220^{\circ} \mathrm{C}$ or from bark at temperatures less than $180^{\circ} \mathrm{C}$.

\subsection{Evaluation of the net LHV of stem chips and bark dried under various conditions}

3.4.1 Net LHV of stem chips The effectiveness of each drying condition was evaluated based on the net LHV, which requires actual measurements of HHV, hydrogen content, and weight yield. Compositional changes due to drying should also be calculated to determine changes in the heating values. Table 1 shows the composition and weight yields of stems dried at different temperatures, and Fig. 5 shows the respective HHV, LHV, and net LHV. Drying time was $30 \mathrm{~min}$. The hydrogen and oxygen contents were found to decrease significantly between 220 and $260^{\circ} \mathrm{C}$, while that of carbon increased. The weight yield of stems also decreased significantly between 220 and $260^{\circ} \mathrm{C}$. The HHV and LHV of stems increased di- 
Table 2 Composition in weight and weight yield of stem chips dried for different lengths of time. Drying temperature: $180^{\circ} \mathrm{C}$

\begin{tabular}{|c|c|c|c|c|c|c|}
\hline $\begin{array}{c}\text { Time } \\
(\mathrm{min})\end{array}$ & $\begin{array}{c}\mathrm{C} \\
(\%)\end{array}$ & $\begin{array}{c}\mathrm{H} \\
(\%)\end{array}$ & $\begin{array}{c}\mathrm{N} \\
(\%)\end{array}$ & $\begin{array}{c}\mathrm{O} \\
(\%)\end{array}$ & $\begin{array}{c}\text { Ash } \\
(\%)\end{array}$ & $\begin{array}{c}\text { Weight } \\
\text { yield (\%) }\end{array}$ \\
\hline 0 & 48.0 & 6.0 & 0.2 & 45.0 & 0.8 & 100.0 \\
\hline 30 & 49.2 & 6.2 & 0.1 & 43.7 & 0.8 & 98.3 \\
\hline 60 & 48.8 & 6.2 & 0.1 & 44.1 & 0.8 & 98.1 \\
\hline 120 & 48.9 & 6.2 & 0.1 & 44.0 & 0.8 & 97.8 \\
\hline
\end{tabular}

rectly with drying temperature. Both moisture release (at $<220^{\circ} \mathrm{C}$ ) and increasing carbon content (between 220 and $260^{\circ} \mathrm{C}$ ) elevated the heating value in unit weight; carbon contributed more to a higher heating value than either hydrogen or oxygen. Both TG and GC-MS results showed that a release of volatile material was activated at temperatures greater than $220^{\circ} \mathrm{C}$, which led to a decrease in the weight yield between 220 and $260^{\circ} \mathrm{C}$. Hence, the HHV and LHV of stems increased with drying temperature.

The data shown in Fig. 5 indicated that the net LHV first increased and then decreased with increasing drying temperature. The decrease in the net LHV between 220 and $260^{\circ} \mathrm{C}$ could clearly be attributed to the decrease in the weight yield. Drying temperatures between 180 and $220^{\circ} \mathrm{C}$ produced the highest net LHV. This region was thus capable of promoting moisture release and deterring the production of volatile material. The drying behavior of stems immersed in distilled water was evaluated (Fig. 2), and the results obtained suggested that the moisture release was less enhanced between 180 and $240^{\circ} \mathrm{C}$. Lower drying temperatures are preferred to process a larger amount of scrap wood under the same drying conditions. Therefore, at drying times of $30 \mathrm{~min}, 180^{\circ} \mathrm{C}$ is the most efficient drying temperature for stem chips. Approximately $4 \%$ of the net LHV increased compared to the starting samples.

\subsubsection{Influence of drying time on the net LHV} of stem chips dried at $180^{\circ} \mathrm{C}$ It was demonstrated above that drying at $180^{\circ} \mathrm{C}$ was the most efficient temperature in order to remove moisture and to extract the net LHV from stem chips. Thus, we next examined the effect of drying time on the net LHV of stem chips. The composition and weight yield of the stem dried for $0-120 \mathrm{~min}$ at $180^{\circ} \mathrm{C}$ are shown in Table 2, and the HHV, LHV, and net LHV of dried stems are shown in Fig. 6. It can be seen from Table 2 that increasing the drying time (from 30 to $120 \mathrm{~min}$ ) negligibly changes either the composition or weight yield of stems. The HHV, LHV, and net LHV of stems, shown in Fig. 6, are also found to be constant even though the drying time increased from 30 to $120 \mathrm{~min}$. These results suggest that moisture released from stems is completed within $30 \mathrm{~min}$. Increasing the drying time does not increase the net LHV. Thus, the drying conditions of $180^{\circ} \mathrm{C}$ and $30 \mathrm{~min}$ are optimal for drying stem chips.

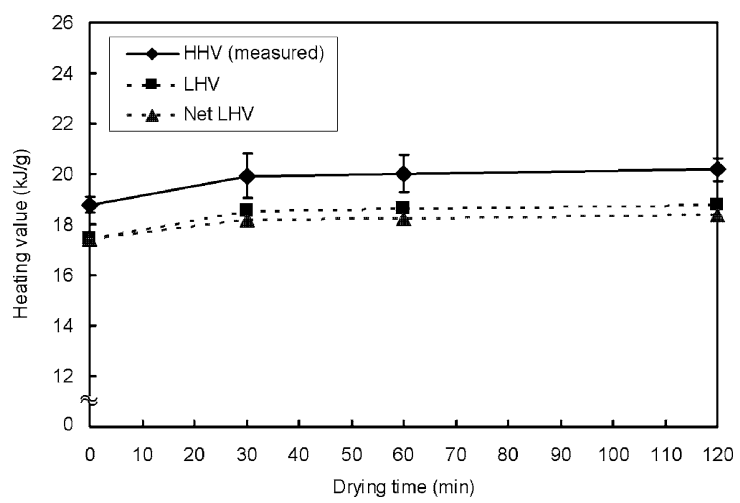

Fig. $6 \mathrm{HHV}$, LHV, and net LHV of stem chips dried for different lengths of time. Drying temperature: $180^{\circ} \mathrm{C}$. Please see the caption of Fig. 5 for an explanation of HHV, LHV, and net LHV. The weight yields shown in Table 2 were used to obtain the net LHV.

Table 3 Composition in weight and weight yield of bark dried at different temperatures. Drying time: $60 \mathrm{~min}$

\begin{tabular}{|c|c|c|c|c|c|c|}
\hline $\begin{array}{c}\text { Temp. } \\
\left({ }^{\circ} \mathrm{C}\right)\end{array}$ & $\begin{array}{c}\mathrm{C} \\
(\%)\end{array}$ & $\begin{array}{c}\mathrm{H} \\
(\%)\end{array}$ & $\begin{array}{c}\mathrm{N} \\
(\%)\end{array}$ & $\begin{array}{c}\mathrm{O} \\
(\%)\end{array}$ & $\begin{array}{c}\text { Ash } \\
(\%)\end{array}$ & $\begin{array}{c}\text { Weight } \\
\text { yield (\%) }\end{array}$ \\
\hline 100 & 49.2 & 5.9 & 0.4 & 42.4 & 2.1 & 100.0 \\
\hline 180 & 50.6 & 5.7 & 0.4 & 41.1 & 2.2 & 97.1 \\
\hline 220 & 54.2 & 5.3 & 0.4 & 37.7 & 2.4 & 91.6 \\
\hline 260 & 54.6 & 4.3 & 0.5 & 37.7 & 2.9 & 75.0 \\
\hline
\end{tabular}

3.4.3 Net LHV of bark The net LHV of dried bark was evaluated to determine the optimal drying conditions. Dried bark was subjected to compositional analysis, weight yield measurement, and evaluation of HHV, LHV, and net LHV. The drying time was set at $60 \mathrm{~min}$ because bark holds more moisture than stem chips (shown in Fig. 2). The changes in the composition and weight yield of the bark due to drying are presented in Table 3 . A large decrease in weight yield was observed at temperatures greater than $220^{\circ} \mathrm{C}$. Drying temperatures up to $220^{\circ} \mathrm{C}$ increase carbon content and decrease the hydrogen and the oxygen contents, while drying temperatures of $260^{\circ} \mathrm{C}$ decrease only the hydrogen content. The HHV, LHV, and net LHV of the bark, as a function of drying temperature, are shown in Fig. 7. Note that the HHV and LHV of bark show little change even though the drying temperature increased. The net LHV of the bark decreased with a decrease in weight yield.

TG and GC-MS results showed that volatile materials were released from the bark at temperatures greater than $180^{\circ} \mathrm{C}$. This indicates that the moisture release increasing the heating value and the release of volatile material reducing the heating value occur simultaneously between 180 and $220^{\circ} \mathrm{C}$. Hence, the net LHV negligibly increased with drying temperature over this range. The optimal drying temperature might be approximately $140^{\circ} \mathrm{C}$. Nevertheless, lower drying temperatures (e.g., $<180^{\circ} \mathrm{C}$ ) are not preferred to accelerate moisture removal in bark (see 


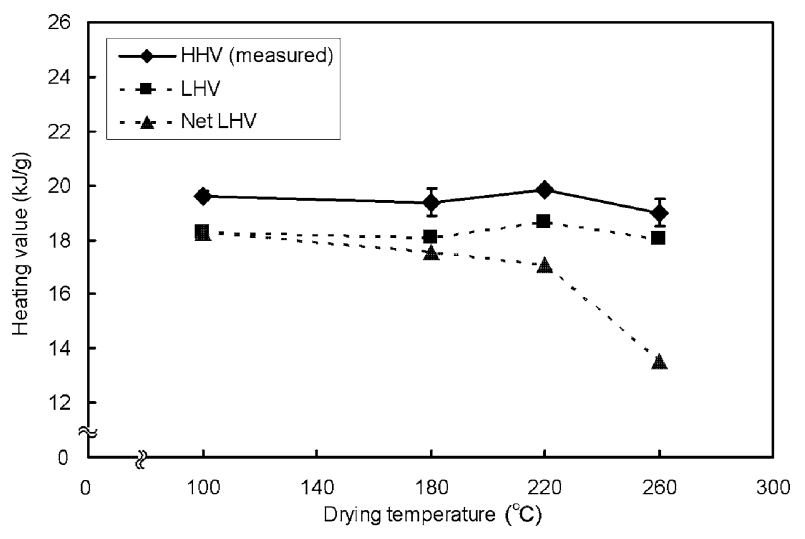

Fig. 7 HHV, LHV, and net LHV of bark dried at different temperatures. Drying time: $60 \mathrm{~min}$. Please see the caption of Fig. 5 for an explanation of HHV, LHV, and net LHV. The weight yields in Table 3 were used to obtain the net LHV.

Fig. 2) but are preferred to maintain its heating value. We should understand that high drying temperatures greater than $180^{\circ} \mathrm{C}$ are not necessary to increase heat release of bark during combustion. Even if bark is more hygroscopic than stems, in the actual plant systems that need to dry them simultaneously, the optimal conditions for stem $\left(180^{\circ} \mathrm{C}\right.$ and $\left.30 \mathrm{~min}\right)$ are likely to be also valid for bark.

\section{Conclusions}

We examined air drying for Japanese cedar stem chips and bark for the purpose of attaining the largest heat release during combustion for efficient power generation in biomass thermal power plants. The conclusions are summarized as follows:

(1) Even though the drying temperature was elevated to $180-240^{\circ} \mathrm{C}$, moisture release of stem and bark was not promoted.

(2) During air drying, volatile components other than moisture were negligibly released from stem at temperatures less than $220^{\circ} \mathrm{C}$ or from bark at temperatures less than $180^{\circ} \mathrm{C}$. The selective removal of moisture was possible at their respective temperature regions.

(3) Based on the variation in the net LHV and the degree of release of moisture and volatile material, the optimal drying conditions were determined to be $180^{\circ} \mathrm{C}$ and $30 \mathrm{~min}$ for stems.

( 4 ) We could not determine the optimal drying conditions for bark. However, we clarified that high drying temperatures greater than $180^{\circ} \mathrm{C}$ are not necessary to in- crease the heat release of bark.

( 5 ) During actual drying processes in biomass thermal power plants, the drying conditions of $180^{\circ} \mathrm{C}$ and 30 min are likely to be valid for combustion of both stem and bark.

\section{Acknowlegements}

The authors would like to thank Dr. S. Sugiyama and Miss K. Sato of the Akita Industrial Technology Center of Akita Prefecture for their help in performing TG and heating value evaluation. Mr. S. Onodera of Akita Prefectural University is highly acknowledged for his assistance in acquiring experimental data.

\section{References}

( 1 ) Obernberger, I., Decentralized Biomass Combustion: State of the Art and Future Development, Biomass and Bioenergy, Vol.14 (1998), pp.33-56.

( 2 ) The Japan Institute of Energy, Biomass Handbook, (in Japanese), (2002), Ohmsya, Ltd.

( 3 ) Ministry of Economy, Trade and Industry of Japan, 2004 Energy White Book, (in Japanese), (2004), Gyosei, Ltd.

(4) Brammer, J.G. and Bridgwater, A.V., The Influence of Feedstock Drying on the Performance and Economics of a Biomass Gasifier-Engine CHP System, Biomass and Bioenergy, Vol.22 (2002), pp.271-281.

( 5 ) Blasi, C.D., Branca, C., Sparano, S. and Mantia, B.L., Drying Characteristics of Wood Cylinders for Conditions Pertinent to Fixed-Bed Countercurrent Gasification, Biomass and Bioenergy, Vol.2.5 (2002), pp.4558.

( 6 ) Larfeldt, J., Leckner, B. and Melaaen, M.C., Modelling and Measurements of Heat Transfer in Charcoal from Pyrolysis of Large Wood Particles, Biomass and Bioenergy, Vol.18 (2000), pp.507-514.

( 7 ) Fagernas, L., Formation and Behavior of Organic Compounds in Biomass Dryer, Bioresource Technology, Vol.46 (1993), pp.71-76.

( 8 ) Hooda, U., Yan, H. and Hittmeier, M.E., HAPs Release from Wood Drying, Environmental Science and Technology, Vol.34 (2000), pp.2280-2283.

(9) Rupar, K. and Sanati, M., The Release of Organic Compound during Biomass Drying Depends upon the Feedstock and/or Altering Drying Heating Medium, Biomass and Bioenergy, Vol.25 (2003), pp.615-622.

(10) Ishikawa, T., Effective Utilization of Waste Heat of Refuse Incineration, (in Japanese), (1996), Riko Tosho, Ltd. 